

\section{Shirkah}

Journal of Economics and Business

Vol. 2, No. 1, January-April 2017

ISSN: 2503-4235 (p); 2503-4243 (e)

\section{Editor in Chief}

Sri Walyoto

\section{Editorial Boards}

Abu Umar Faruq Ahmad, UBD School of Business and Economics, Brunei Darussalam

Amelia Fauzia,

Asia Research Institute, National University of Singapore, Singapore

Cedomir Nestorovic,

ESSEC Business School Asia Pacific, Singapore

Dwi Condro Triono,

Faculty of Islamic Economics and Business, IAIN Surakarta, Indonesia

Fahmy Radhi,

Faculty of Economics and Business Universitas Gadjah Mada, Yogyakarta,

Indonesia

Hasan Basri,

Syiah Kuala University, Aceh, Indonesia

Johan Fischer,

Department of Social Sciences and Business Roskilde University, Denmark

Masudul Alam Choudhury,

Postgraduate Program in Islamic Economics and Finance, Trisakti University,

Jakarta, Indonesia and the College of Economics and Political Science (CEPS) in

Sultan Qaboos University (SQU), Oman

M. Falik Isbah,

School of Humanities and Social Science, University of New South Wales, Australia M. Ishaq Bhatti,

La Trobe Business School Department of Economics and Finance La Trobe

University, Australia

Najib Kailani,

Pascasarjana, Universitas Islam Negeri (UIN) Sunan Kalijaga, Yogyakarta, Indonesia 
Nunung Nurul Hidayah,

Aston Business School, Aston University, Birmingham, United Kingdom

Shaikh M Ghazanfar,

Departement of Economics, University of Idaho, Russian Federation

\section{Managing Editors}

Fitri Wulandari

Jasanta Perangin-angin

\section{Assistant to Editor}

M. Endy Saputro

M. Zainal Anwar

Supriyanto

Shirkah Journal of Economics and Business is a peer-reviewed journal published three times a year (January-April, May-August and September-December) by Faculty of Islamic Economics and Business, Institut Agama Islam Negeri (IAIN/ State Institute for Islamic Studies) Surakarta Central Java, Indonesia. The main objective of Shirkah is to offer an academic space of exchange ideas and initiate the increase number of qualified article produced by postgraduate students, practitioners and academicians.

\section{Editorial Office}

Ruang Jurnal Shirkah

Ground Floor, West Gate,

Faculty of Islamic Economics and Business

IAIN Surakarta

Jln. Pandawa No. 1, Kartasura, Sukoharjo, Jawa Tengah Kode Pos. 57168

Phone (+62271) 781516 Fax: (+62271)782336

E-mail: shirkahiainsurakarta@gmail.com

Website: http://shirkah.or.id/ 



\section{Shirkah}

Journal of Economics and Business

Vol. 2, No. 1, January-April 2017

ISSN: 2503-4235 (p); 2503-4243 (e)

\section{Table of Contents}

\section{Articles}

Ana Zahrotun Nihayah

Savings and Loans Program, The Revenue of Small Micro Entreprises and Poverty Reduction among Women Groups

Ana Fadhilah

Muslimah Entrepreneurship and Economic Empowerment in Pengajian

Umiyati

Local Economics Empowerment and Sharia Microfinance in Rural

Community Perception

Lathif Hanarif Rifqi

Community Empowerment through Islamic Microfinances Perceptions in Comparison

Ahmad Lukman Nugraha

Islamic Business Ethics and Islamic Microfinance in Pesantren Gontor

Nova Ch. Mamuaya

Service Quality and Non-Muslim Satisfaction Using Sharia Bank Products and Services 



\title{
Service Quality and Non-Muslim Satisfaction Using Sharia Bank Products and Services
}

\author{
Nova Ch. Mamuaya \\ Universitas Negeri Manado \\ chrismy_college@yahoo.com
}

\begin{abstract}
s
Some studies show that religious belief does not take effect affecting consumer using sharia bank products and services. This research has implemented six dimensions of Othman and Owen which modified five dimensions of Parasuraman with adding compliance dimension. The six dimensions of Othman \& Owen are known as CARTER (compliance, assurance, reliability, tangible, empathy, and responsiveness). The research purpose is to analyze compliance, assurance, reliability, tangible, empathy, and responsiveness effect on non-Muslim customer satisfaction on sharia bank products and services at Manado Sulawesi Utara partially or simultaneously. The data was gathered with questionnaire instruments of 70 respondents, measured with five Likert scale five dots. The research result shows compliance, assurance, reliability, tangible, empathy, and responsiveness has significant effect on customer satisfaction. Responsive has most strong effect and compliance is the weakest.
\end{abstract}

Keywords: Sharia Bank, non-Muslim, quality service, customer satisfaction, Manado

\section{Introduction}

Sharia bank development at North Sulawesi, especially Manado shows positive enhancement. It is shown from the assembling of third party fund (Dana Pihak Ketiga/ DPK) consists of increasing saving, deposit, and clearing. The growth in 2012 is $41.22 \%$ compared to the previous year (year on year). The three types of DPK at Manado sharia bank got significant attention from Manado community; its growth is the 
evidence. The highest enhancement was the clearing, achieving fantastic enhancement at $97.52 \%$. The fund goes to enter the Manado sharia bank clearing account in 2012 was 33.04 billion rupiahs. The amount was highly raised from 2011 income with 16.73 billion rupiahs. Other assembling fund, namely from saving had raised $40.37 \%$ compared to the previous year. The deposit, even with the lower amount, its raising was significantly high around $28.79 \%$. The assembling saving at sharia bank was 144.8 billion rupiahs, increasing from 2011 amount of 103.2 billion rupiahs. The deposit amount was only 68.7 billion rupiahs in 2011 increased becoming 88.45 billion rupiahs in 2012. The sharia bank operating at Manado in 2013 was 3 banks, namely Mandiri, Muamalat, and Mega; with 13 office networks to service (BI Sulut Representation, 2013).

Sharia bank DPK enhancement is the evidence the sharia bank existence is well accepted and entrusted by Manado community. The interesting fact of the sharia principle applied bank existence in Manado is $75 \%$ of its customers are non-Muslim (BI Sulut Representation, 2013). It means Manado community considers sharia bank provide adding values and utilities, and do not consider it only for certain religion whereas as open financial institution for all people.

Several studies show that religious belief is not the main factor affecting consumer in using sharia bank products and services; and also the free interest or riba factor (Yuliansyah, 2016). Service quality is the main factor affecting non-Muslim customers in using sharia bank products and services (Hidayat \& Al-Bawardi, 2012; Akbar, Shah, Kalmadi, 2012; Qureshi, Khan, Zaman, 2012; Ameer, 2013). These studies did not analyze how service quality affects the non-Muslim customer satisfaction on sharia bank products and services. Most studies on service quality was using five dimensions of Parasuraman, Zeithaml, Berry (1988) namely, reliability, empathy, tangible, responsiveness, and assurance. This research was 
implementing six dimensions from Othman \& Owen (2001) modifying the five dimensions from Parasuraman, Zeithaml, Berry (1988) adding compliance dimension. The six dimensions from Othman \& Owen is known with CARTER as instrument name, more accurate to measure service quality of sharia bank.

\section{Service Quality}

Kotler (2005) defines quality with utility accuracy, need accuracy, free of deviance and so on. According to American Society for Quality Control service quality is the entire characteristics or the nature of thing and service affecting the ability to fulfill explicit and implicit needs. Parasuraman, Zeithaml, Berry (1988) mentioned five service quality determinant namely reliability, responsiveness, assurance, empathy, and tangibles. Othman \& Owen (2001) stated that the Islamic Bank significance to adopt service quality. The research result shows the suggestion to use new model of sharia bank service quality measurement called CARTER (Compliance, Assurance, Reliability, Tangibles, Empathy, and Responsiveness). The indicators are 34 items.

Compliance, (fulfillment) is the ability to fulfill Islamic law and operating base on the Islamic banking and economic principles (Othman \& Owen, 2001). This dimension is the additional dimension to SERVQUAL five dimensions usually used on service quality studies. The additional is due to SERVQUAL less specific for Islamic bank or other sharia services institution. The compliance variable items in this research are: no interest element, bank operational in accordance with Islamic sharia, Islamic products and services, and applying profit sharing system.

Assurance, Kotler (2005), Lupiyoadi (2001), and Othman \& Owen (2001) define assurance as mentioned by Parasuraman, Zeithaml, Berry (1988), and also four other dimensions (reliability, tangibles, empathy, 
and responsiveness). Assurance is employee knowledge, politeness, and increasing customer entrust to the company. The assurance items in this research are: employee knowledge on products, employee hospitality, safety, and trust in using bank services.

Reliability, is ability to provide promised services with accuracy and trust. The items in this research are: promises fulfilling accuracy, transaction record accuracy, products variation, and needed services (Belaid, 2017). Tangibles, (physical evidence) are physical presentation, tools, personal, and communication material. According to Lupiyoadi (2000) physical evidence relates to company ability to show its existence to external parties. The items in this research are: building appearance, building interior, employee appearance, using tools, and transaction facility.

Empathy is ability to care; giving personal attention to the customer, Lupiyoadi (2001) argues that sincere and personal attention, including the effort to understand consumer needs is included in empathy. The items in this research are: waiting room comfort, special assistance and attention; and service hours. Responsiveness, is the ability to assist customer and providing rapid services. Lupiyoadi (2001) added providing comprehensible information. The items in this research are: queue, rapid service, and employee response to customers' needs.

The are some several definitions of satisfaction (Tjiptono, 2012). The feeling emerged after the evaluation of products using experience. Customer response on perception evaluation of the difference between initial expectation before purchase (or other performance standard) and actual products performance before perceived after products using or consumption. Post purchase comprehensive evaluation comparing perception with products performance with pre-purchase expectation. The performance measurement of "total product" of an organization comparing to a set of customer requirements. Individual feeling level after comparing performance (or result) he/ she perceived with the expectation. 


\section{Service Quality and Consumer Satisfaction}

Service quality is comprehensive characteristic or the nature of things and services with the effect on ability to fulfill explicit or implicit needs (Ismal, 2010). Othman \& Owen (2001) offered to use the new model in measuring sharia bank service quality with CARTER (Compliance, Assurance, Reliability, Tangibles, Empathy, and Responsiveness). Customer satisfaction is customer response on perception evaluation of the difference between initial expectation pre-purchase (or other standard performance) and actual products performance as perceived after using on consumption on the related products (Tjiptono, 2012).

The services measured by (Compliance, Assurance, Reliability, Tangibles, Empathy, and Responsiveness will be able to fulfill customer satisfaction (Quttainah, 2017). The perspective above shows Compliance, Assurance, Reliability, Tangibles, Empathy, and Responsiveness will affect the customer satisfaction (Manna, 2017). 


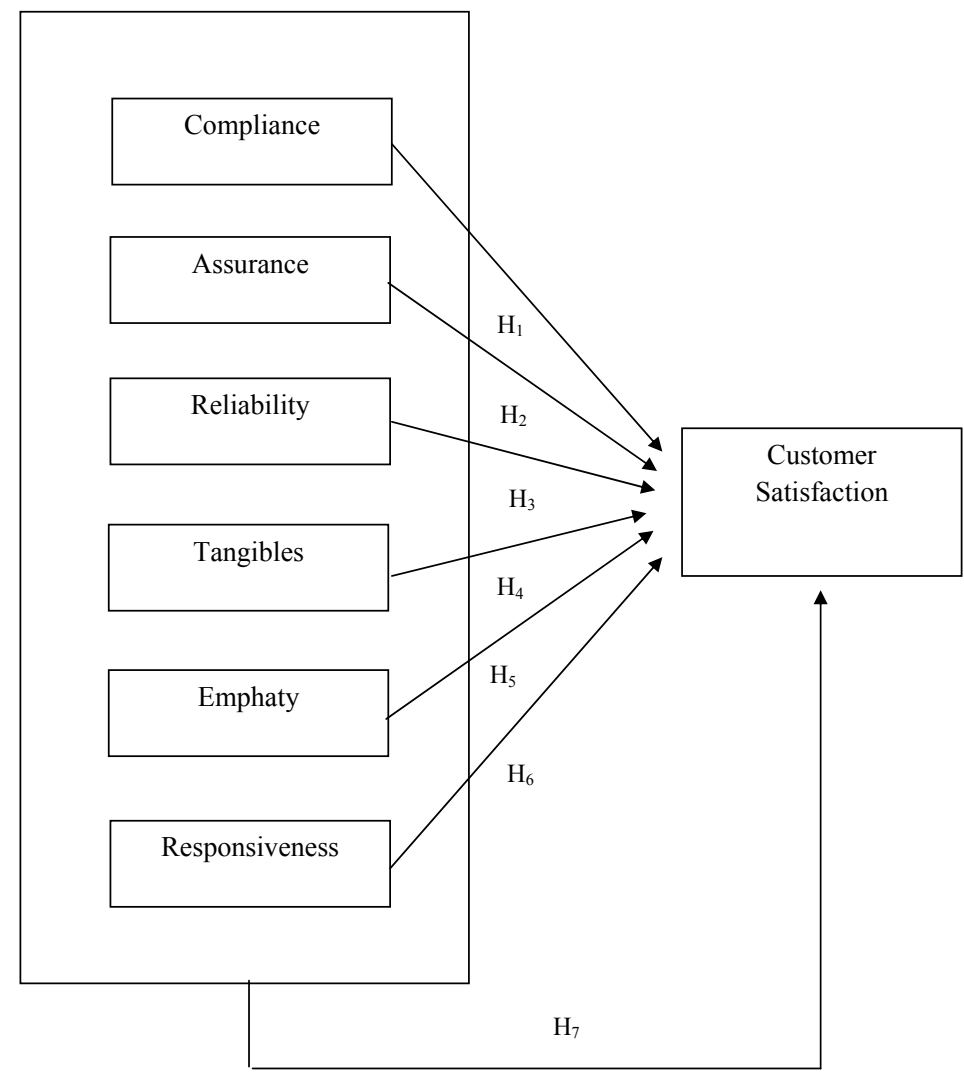

Picture 1: Conceptual Framework

\section{Hypothesis and Research Design}

The theoretical framework and conceptual framework established the hypothetical research formulation as follows. (H1) The compliance has effect on non-Muslim customer satisfaction on sharia bank products and services at Manado Sulawesi Utara. (H2) The assurance has effect on non-Muslim customer satisfaction on sharia bank products and services at Manado Sulawesi Utara. (H3) The reliability has effect on non-Muslim customer satisfaction on sharia bank products and services at Manado Sulawesi Utara. (H4) The tangible has effect on non-Muslim customer 
satisfaction on sharia bank products and services at Manado Sulawesi Utara. (H5) The empathy has effect on non-Muslim customer satisfaction on sharia bank products and services at Manado Sulawesi Utara. (H6) The responsiveness has effect on non-Muslim customer satisfaction on sharia bank products and services at Manado Sulawesi Utara. (H7) The compliance, assurance, reliability, tangibles, empathy, and responsiveness collectively have effect on non-Muslim customer satisfaction on sharia bank products and services at Manado Sulawesi Utara.

This research is survey research namely research taking sample from the population using questionnaire as main data collecting instrument. Therefore the research is categorized as explanatory research due to its explanation causal relation between the research variables with hypothetical test (Singarimbun \& Sofian, 2006). In accordance with the research purpose, the tested variables are independent variable and dependent variable. The independent variables $(\mathrm{X})$ are compliance $\left(\mathrm{X}_{1}\right)$, assurance $\left(\mathrm{X}_{2}\right)$, reliability $\left(\mathrm{X}_{3}\right)$, tangibles $\left(\mathrm{X}_{4}\right)$, empathy $\left(\mathrm{X}_{5}\right)$, and responsiveness $\left(\mathrm{X}_{6}\right)$. The dependent variable is customer satisfaction $(\mathrm{Y})$.

The research variable definition is explained on Table 1 below:

Table 1: Research Variable Definition

\begin{tabular}{|c|c|c|}
\hline Variable & $\begin{array}{c}\text { Variable Concept } \\
\text { Definition }\end{array}$ & Indicators \\
\hline Compliance $\left(\mathrm{X}_{1}\right)$ & $\begin{array}{l}\text { Ability to apply Islamic law } \\
\text { and operate base on Islamic } \\
\text { economy principles and } \\
\text { banking. }\end{array}$ & $\begin{array}{l}\text { 1. No interest element } \\
\text { 2. Bank operation follows } \\
\text { Islamic sharia } \\
\text { 3. Islamic products } \\
\text { 4. Islamic services } \\
\text { 5. Operating profit sharing } \\
\text { system }\end{array}$ \\
\hline
\end{tabular}




\begin{tabular}{|c|c|c|}
\hline Assurance $\left(\mathrm{X}_{2}\right)$ & $\begin{array}{l}\text { Employee knowledge, } \\
\text { politeness, and ability to } \\
\text { establish customer trust for } \\
\text { the company. }\end{array}$ & $\begin{array}{l}\text { 1. Employee knowledge on } \\
\text { company products } \\
\text { 2. Employee hospitality } \\
\text { 3. Security in using bank } \\
\text { services } \\
\text { 4. Trust in using bank services }\end{array}$ \\
\hline Reliability $\left(\mathrm{X}_{3}\right)$ & $\begin{array}{l}\text { Ability to provide promised } \\
\text { services accurately and } \\
\text { trustworthy }\end{array}$ & $\begin{array}{ll}\text { 1. } & \text { Promise fulfillment } \\
\text { accuracy } \\
\text { 2. Transaction record } \\
\text { accuracy } \\
\text { 3. Needed products variation } \\
\text { 4. Needed services variation }\end{array}$ \\
\hline Tangibles $\left(\mathrm{X}_{4}\right)$ & $\begin{array}{l}\text { Company ability to express } \\
\text { its existence to the external } \\
\text { parties }\end{array}$ & $\begin{array}{l}\text { 1. Building appearance } \\
\text { 2. Building interior } \\
\text { appearance } \\
\text { 3. Employee appearance } \\
\text { 4. Using tools } \\
\text { 5. Transaction facilities }\end{array}$ \\
\hline Emphaty $\left(\mathrm{X}_{5}\right)$ & $\begin{array}{l}\text { Willingness to care, } \\
\text { providing personal } \\
\text { attention to customer }\end{array}$ & $\begin{array}{ll}\text { 1. } & \text { Room comfort } \\
\text { 2. } & \text { Special assistance } \\
\text { 3. } & \text { Special attention } \\
\text { 4. } & \text { Services hours }\end{array}$ \\
\hline Responsiveness $\left(\mathrm{X}_{6}\right)$ & $\begin{array}{l}\text { Ability to assist customer } \\
\text { and providing rapid } \\
\text { services }\end{array}$ & $\begin{array}{ll}\text { 1. } & \text { Queue duration } \\
\text { 2. } & \text { Services speed } \\
\text { 3. Employee response on } \\
\text { customer needs }\end{array}$ \\
\hline $\begin{array}{l}\text { Customer } \\
\text { Satisfaction (Y) }\end{array}$ & $\begin{array}{l}\text { Customer response on } \\
\text { perception evaluation of } \\
\text { the difference between } \\
\text { intial expectation before } \\
\text { purchase (or other } \\
\text { performance standard) } \\
\text { and products actual } \\
\text { performance as perceived } \\
\text { after related products using } \\
\text { or consumption }\end{array}$ & $\begin{array}{l}\text { 1. Recommending Manado } \\
\text { sharia bank to other } \\
\text { people } \\
\text { 2. Undesired feeling to move } \\
\text { to other banks }\end{array}$ \\
\hline
\end{tabular}

The sample is subset of population, consists of several population member. The subset was taken due to impossibility to study all population members. Therefore population representation was established and called 
sample (Ferdinand, 2006). The research sample size determination was following the guidance stated by Sekaran (2006). It states multivariate research (including multiple regression analysis) the sample size minimum is 10 times of the studied variable amount. The studied variables in this research are 7 , consists of 6 independent variables (compliance, assurance, reliability, tangibles, empathy, and responsiveness) and 1 dependent variable, customer satisfaction. Based on Sekaran (2006) guidance mentioned above the minimum sample is $10 \times 7=70$ respondents.

Technique of taking sample is accidental sampling. According to Sugiyono (2008), accidental sampling is sampling technique and based on coincident. It means whoever meet with the researcher was able to be used as sample, whereas the person is accurate as data source. Purposive sampling is used to choose 70 respondents with criteria as follows: not sharia bank employee able to directly enjoy products and services, has more than once transaction per month, and has ever used sharia products and services more than one.

The data source in used consists of primary data and secondary data. Primary data is research data directly gained from original source (without mediator) (Indriantoro \& Supomo, 2002). The primary data in this research was earned from the first source namely sharia bank customer at Manado: Mandiri, Muamalat, and Mega. Primary data gathered with questionnaire as main instrument whereas secondary data are gained for documentation of sharia bank internal information, Bank Indonesia, newspaper, online media, books, and relevant journal.

The questionnaire in this research is written in statement sentences and respondents were asked to answer with making cross $(\mathrm{X})$ sign. The respondent answers were measured with Likert scale. According to Sekaran (2006), Likert scale was designed to measure the strength of respondent's agree or disagree with the statement of 5 points scale with composition as 
follows: Highly Disagree $=1$, Disagree $=2$, Neutral $=3$, Agree $=4$, Highly Agree $=5$. It means the value range of the Likert scale is between score 1 at the lowest level (highly disagree), and score 5 at the highest answer (highly agree.)

Analysis of this research is multiple regressions involving one dependent variable and two or more independent variable (Maholtra, 2005). Multiple regression equation formula is stated as follows

$$
\mathrm{Y}=\mathrm{a}+\mathrm{b}_{1} \mathrm{X}_{1}+\mathrm{b}_{2} \mathrm{X}_{2}+\mathrm{b}_{3} \mathrm{X}_{3}+\ldots+\mathrm{b}_{\mathrm{k}} \mathrm{X}_{\mathrm{k}}+\mathrm{e}
$$

Explanation:

$Y=$ dependent variable

$a=$ intercept (crossing point) with line

$b_{1}-b_{k}=k$ regression coefficient independent variables

$X 1-X_{k}=$ independent variables

$e=$ error

The independent variables $(\mathrm{X})$ in this research are compliance $\left(\mathrm{X}_{1}\right)$, assurance $\left(\mathrm{X}_{2}\right)$, reliability $\left(\mathrm{X}_{3}\right)$, tangibles $\left(\mathrm{X}_{4}\right)$, empathy $\left(\mathrm{X}_{5}\right)$, and responsiveness $\left(\mathrm{X}_{6}\right)$; whereas the dependent variable $(\mathrm{Y})$ is the customer satisfaction. Therefore the multiple regression equation in this research is stated below:

$$
\mathrm{Y}=\mathrm{a}+\mathrm{b}_{1} \mathrm{X}_{1}+\mathrm{b}_{2} \mathrm{X}_{2}+\mathrm{b}_{3} \mathrm{X}_{3}+\mathrm{b}_{4} \mathrm{X}_{4}+\mathrm{b}_{5} \mathrm{X}_{5}+\mathrm{b}_{6} \mathrm{X}_{6}+\mathrm{e}
$$

Explanation:

$Y=$ customer satisfaction

$a=$ intercept

$b_{1}-b_{6}=k$ regression coefficient independent variable

$X_{1}=$ compliance

$X_{2}=$ assurance

$X_{3}=$ reliability

$X_{4}=$ tangibles

$X_{5}=$ empathy

$X_{6}=$ responsiveness

$e=$ error 


\section{Hypothetical Test}

The test was conducted with trust degree of $5 \%$ and freedom degree/ $\mathrm{df}=(\mathrm{k}-1)$ and $(\mathrm{n}-\mathrm{k})$. The conclusion of hypothetical test result is conducted with $\mathrm{t}$ test and F test using SPSS for MS Windows Program. The $t$ test was conducted to show whereas independent variables are partially affecting the dependent variable. According to Ghozali (2005), the hypothesis test is able to be conducted with quick look. The decision taking criteria are whereas $\mathrm{t}_{\text {calculation }}$ value is bigger than 2 (in absolute value) therefore $\mathrm{H}_{\mathrm{o}}$ is able to be rejected at trust degree $5 \%$ or in other word alternative hypothesis $\left(\mathrm{H}_{\mathrm{a}}\right)$ is accepted. The dominant independent variable over dependent variable will be found out using standardized Beta coefficient.

F test was conducted to show whereas independent variables have simultaneous effect on dependent variables. Ghozali (2005) said that hypothesis test could be conducted with quick look. The quick look will show decision making criteria are whereas $\mathrm{F}_{\text {calculation }}$ value is bigger than 4 therefore $\mathrm{H}_{\mathrm{o}}$ is able to be rejected at trust degree $5 \%$ or in other word alternative hypothesis $\left(\mathrm{H}_{\mathrm{a}}\right)$ is accepted.

\section{Non-Muslim Satisfaction Result}

The multiple regression analysis using $\mathrm{t}$ test and $\mathrm{F}$ test shows compliance, assurance, reliability, tangibles, empathy, and responsiveness have significant effect partially and simultaneously on non-Muslim customer satisfaction of sharia bank services and products at Manado Sulawesi Utara. The $t$ test shows $t_{\text {calculation }}$ and significance of compliance, assurance, reliability, tangibles, empathy, and responsiveness shown on Table 1 below: 
Table 1: $t_{\text {calculation }}$ Value and Independent Variable Significance

\begin{tabular}{|l|c|c|c|}
\hline \multicolumn{1}{|c|}{ Variable } & t- ${ }_{\text {calculation }}$ & Sig. & Explanation \\
\hline Compliance $\left(\mathrm{X}_{1}\right)$ & 2,190 & 0,031 & Significant \\
\hline Assurance $\left(\mathrm{X}_{2}\right)$ & 4,706 & 0,000 & Significant \\
\hline Reliability $\left(\mathrm{X}_{3}\right)$ & 3,056 & 0,003 & Significant \\
\hline Tangibles $\left(\mathrm{X}_{4}\right)$ & 3,659 & 0,000 & Significant \\
\hline Empathy $\left(\mathrm{X}_{5}\right)$ & 4,706 & 0,000 & Significant \\
\hline Responsiveness $\left(\mathrm{X}_{6}\right)$ & 12,476 & 0,000 & Significant \\
\hline
\end{tabular}

Source: Processed primary data (2015)

Table 1 shows $\mathrm{t}_{\text {calculation }}$ of compliance is 2.190; assurance is 4.706; reliability is 3.056, tangible is 3.659; empathy is 4.706; and responsiveness is 12.476. Hypothesis test using quick look the $t_{\text {calculation }}$ of compliance, assurance, reliability, tangibles, empathy, and responsiveness $>2$ or whereas seen from $t_{\text {calculation }}$ significant value, the five independent variables have significant value $<0.05$. it means compliance, assurance, reliability, tangibles, empathy, and responsiveness has partially significant effect on non-Muslim customer satisfaction about sharia bank products and services at Manado Sulawesi Utara. Therefore the hypothesis 1-6 of this research is accepted.

T test result using standardized Beta coefficient shows responsiveness has dominant effect on non-Muslim satisfaction of sharia bank products and services at Manado Sulawesi Utara with standardized coefficient of 0.797. The compliance has the smallest effect with standardized coefficient of 0.124 . The Beta standardized coefficient of each independent variable is shown on Table 2 below: 
Table 2: Beta Standardized Coefficients Value

\begin{tabular}{|l|c|}
\hline \multicolumn{1}{|c|}{ Variable } & Standardized Coefficients Beta \\
\hline Compliance $\left(\mathrm{X}_{1}\right)$ & 0.124 \\
\hline Assurance $\left(\mathrm{X}_{2}\right)$ & 0.326 \\
\hline Reliability $\left(\mathrm{X}_{3}\right)$ & 0.206 \\
\hline Tangibles $\left(\mathrm{X}_{4}\right)$ & 0.270 \\
\hline Empathy $\left(\mathrm{X}_{5}\right)$ & 0.326 \\
\hline Responsiveness $\left(\mathrm{X}_{6}\right)$ & 0.797 \\
\hline
\end{tabular}

Source: Processed primary data (2015)

The $\mathrm{F}$ test shows significant $\mathrm{F}_{\text {calculation }}$ and probability shown on Table 3 below:

Table 3: Significant $F_{\text {calculation }}$ Value

\begin{tabular}{|c|c|c|}
\hline $\mathbf{F}_{\text {calculation }}$ & Sig & Explanation \\
\hline 56,187 & 0,000 & Significant \\
\hline
\end{tabular}

Source: Processed Primary data (2015)

Table 3 shows $\mathrm{F}_{\text {calculation }}$ value is 56.187 . The hypothesis $\mathrm{t}$ test using quick look shows $\mathrm{F}_{\text {calculation }}>4$ or shown of $\mathrm{F}_{\text {calculation }}$ significant value 0.000 $<0.05$. It means compliance, assurance, reliability; tangibles, empathy, and responsiveness simultaneously have significant effect on non-Muslim customer satisfaction of sharia bank at Manado Sulawesi Utara. Therefore the hypothesis 7 is accepted.

\section{Conclusions}

The compliance has positive and significant effect on non-Muslim customer satisfaction of sharia bank products and services at Manado Sulawesi Utara. It means the compliance enhancement will enhance customer satisfaction. Compliance has smallest effect on non-Muslim customer satisfaction of sharia bank products and services at Manado 
Sulawesi Utara. The assurance has positive and significant effect on nonMuslim customer satisfaction of sharia bank products and services at Manado Sulawesi Utara. It means the assurance enhancement will enhance customer satisfaction.

The reliability has positive and significant effect on non-Muslim customer satisfaction of sharia bank products and services at Manado Sulawesi Utara. It means the reliability enhancement will enhance customer satisfaction. The tangible has positive and significant effect on non-Muslim customer satisfaction of sharia bank products and services at Manado Sulawesi Utara. It means the tangible enhancement will enhance customer satisfaction.

The empathy has positive and significant effect on non-Muslim customer satisfaction of sharia bank products and services at Manado Sulawesi Utara. It means the empathy enhancement will enhance customer satisfaction. The responsiveness has positive and significant effect on non-Muslim customer satisfaction of sharia bank products and services at Manado Sulawesi Utara. It means the responsiveness enhancement will enhance customer satisfaction. Compliance has dominant effect on non-Muslim customer satisfaction of sharia bank products and services at Manado Sulawesi Utara. The compliance, assurance, reliability, tangibles, empathy, and responsiveness simultaneously have positive and significant effect on non-Muslim customer satisfaction of sharia bank products and services at Manado Sulawesi Utara.

\section{References}

Akbar, S., Shah, S.Z.A., Kalmadi, S. (2012). An Investigation of User Perceptions of Islamic Banking Practices in the United Kingdom. International Journal of Islamic and Middle Eastern Finance and 
Management, Vol. 5, No. 4, 353-370.

Belaid, F., Boussaada, R., Belguith, H. (2017). Bank-Firm Relationship and Credit Risk: An Analysis on Tunisian Firms. Research in International Business and Finance 42. pp. 532-543.

Cronin, J.J.Jr \& Steven A.T. (1994). SERVPERV Versus SERVQUAL: Reconciling Performance-Based and Percepcion-minus-Expectations Measurement of Service Quality. Journal of Marketing, Vol.58, 125 -131 .

Ferdinand, A. (2006). Metode Penelitian Manajemen, Pedoman Penelitian untuk Penulisan Skripsi, Tesis dan Disertasi Ilmu Manajemen. Edisi Dua. Semarang: Badan Penerbit Universitas Diponegoro.

Hidayat, S.E., \& Al-Bawardi, N.K. (2012). Non-Muslims' Perceptions Toward Islamic Banking Services in Saudi Arabia. Journal of US Journal of US-China Public Administration, ISSN 1548-6591, Vol. 9 , No. 6, 654-670.

Imam Ghozali. (2005). Aplikasi Analisis Multivariate dengan Program SPSS. Edisi 3. Semarang: Badan Penerbit Universitas Diponegoro.

Ismal, R. (2010). Strengthening and Improving the Liquidity Management in Islamic Banking. Humanomics 26 (1), pp. 18-35.

Kotler, P. (2005). Manajemen Pemasaran. Jakarta: Indeks Kelompok Gramedia.

Lupiyoadi, R. (2001). Manajemen Pemasaran Jasa : Teori dan Praktik. Jakarta: Salemba Empat.

Malhotra, Naresh K. (2005). Riset Pemasaran Pendekatan Terapan. Edisi Keempat. Jilid 1. Jakarta: Indeks Kelompok Gramedia.

Malhotra, Naresh K. (2005). Riset Pemasaran Pendekatan Terapan. Edisi Keempat. Jilid 2. Jakarta: Indeks Kelompok Gramedia.

Manna, E. (2017). Customer-Oriented Employees: Blessing or Curse for Firms?. Journal of Economics and Management Strategy 26 (4), pp. 842-875. 
Nur Indriantoro \& Bambang Supomo. (2002). Metodologi Penelitian Bisnis untuk Akuntansi dan Manajeman. Edisi Pertama. Yogjakarta: BPFE-UGM.

Othman, A., \& Owen, L. (2001). Adopting and Measuring Customer Service Quality (Sq) In Islamic Banks: A Case Study In Kuwait Finance House. International Journal of Islamic Financial Services, 3(1), 1-26.

Parasuraman, A., Zeithaml, W., \& Berry, L. (1988). SERVQUAL: a Multiple Item Scale for Measuring Consumer Perceptions of Service Quality. Journal of Retailing, 64 (1), 2-40.

Parasuraman, A., et al. (1994). Reassestmentof Expectation as a Comparison Standard in Measuring Service Quality. Journal of Marketing, Vol 58, 111-124.

Qureshi, M. I., Khan, A., \& Zaman, K. (2012). Structural Investigation of Service Quality in Conventional and Islamic Banking in Pakistan. International Review of Management and Marketing, 2(2), 99-105.

Quttainah, M.A., Almutairi, A.R. (2017). Corporate Ethics: Evidence from Islamic Banks. Journal of Management and Govenance 21 (4). pp. 815-840.

Sekaran, Uma (2006). Metodologi Penelitian untuk Bisnis. Penerjemah:

Kwan Men Yon. Edisi 4. Buku 2. Jakarta: Salemba Empat.

Singarimbun, M \& Sofian E. (2006). Metode Penelitian Survey. Edisi Revisi. Jakarta: LP3ES.

Singgih Santoso. (2002). SPSS Statistik Multivariate. Jakarta: Elex Media Komputindo.

Sugiyono. (2008). Metode Penelitian Bisnis (Pendekatan Kuantitatif, Kualitatif, dan R \& D). Bandung: Alfabeta.

Teas, R.Kenneth. (1994). Expectations as a Comparison Standart in Measuring Service Quality : An Assestment of a Reassestment. Journal of Marketing, Vol. 58, 132-139.

Tjiptono, F. (2012). Service Management, Mewujudkan Layanan Prima. Yogjakarta: Andi. 
Yuliansyah. (2016). The Leverage of Financing Performance Through Knowledge Sharing Using a System of Interactive Measurement of Performance. International Business Management 10 (3), pp. 200-208. 


\section{Shirkah Author Guidelines}

Shirkah currently offers two routes to submit manuscripts. We highly recommend to submit the articles which are made using OJS (Open Journal System). Feel free register as author soon through visiting http:// shirkah.or.id/index.php/home/user/register. The authors may directly send their manuscripts, along with their resume, to shirkahiainsurakarta@ gmail.com. Please prepare your manuscripts, using following guidelines:

1. Manuscript must be written in English. Submitted articles should not have been published or be under review for publication with another journal.

2. Manuscript's length is about $15-20$ pages, typed in one-half spaced on A4-paper size.

3. Manuscript must include an $150-200$ word abstract and keywords.

4. Manuscript must be arranged as follows: Title, Name of Author, E-mail address, Abstract, Keywords, Introduction (including method if any), Discussion, Conclusion, References.

5. Manuscript's titles not more than ten words.

6. Manuscript must be submitted in Microsoft Word or RTF.

7. Arabic words should be transliterated according to the style of International Journal of Middle Eastern Studies.

8. Manuscript references are preferably derived from the up-to-date references.

9. The author's resume should be submitted separately, consisting of at least full name, institutional address, phone number, areas of studies, and recent publications (if any).

10. Shirkab use APA Style 6th edition (2010) as reference format writing. We suggest the use of a reference manager software such as Mendeley, Zotero, and Endnote at templating the citation style. APA Style to be used is as follows: 


\section{Book with single author}

Swann, G. M. Peter. (2014). The Economics of Innovation an Introduction. Cheltenhum \& Northampton: Edward Elgar.

in-text citation: (Swann, 2014)

\section{Articles in reference books}

Alatas, S. F. (2006). Islam and the Science of Economics in Abu Rabi', I.M. The Blackwell Companion to Contemporary Islamic Thought. USA: Willey-Blackwell (pp. 587-606).

in text citation: (Alatas, 2006)

\section{E-Book}

Hackett, Rosalind (2007). "Religous Dimentions of War and Peace: Introduction.” Dalam Gerrie ter Haar dan Yoshio Tsuruoka (Ed.), Religion and Society: An Agenda for the 21st Century (h. 3-6). Retrieved from http:// brill.nl.

in text citation: (Hackett, 2006)

\section{Master's thesis, from a commercial database}

McNieI, D. S. (2006). Meaning through narrative: A personal narrative discussing growing up with an alcoholic mother (Master's thesis). Available from ProQuest Dissertations and Theses database. (UMI No. 1434728)

in text citation: (Mc Niel, 2006)

\section{Doctoral dissertation, from an institutional database}

Adams, R. J. (1973). Building a foundation for evaluation of instruction in higher education and continuing education (Doctoral dissertation). Retrieved from http://www.ohiolink.edu/etd/

in text citation: (Adams, 1973) 


\section{Doctoral dissertation, from the web}

Bruckman, A. (1997). MOOSE Crossing: Construction, community, and learning in a networked virtual world for kids (Doctoral dissertation, Massachusetts Institute of Technology). Retrieved from http:/www-static. cc.gatech.edu/--asb/thesis/ in text citation: (Bruckman, 1997)

\section{Journal article with No DOI}

Bourkhis, K., and Nabi, M. S. (2013). Islamic and conventional banks' soundness during the 2007-2008 financial crisis. Journal Metrics, 22(2), 68-77.

in-text citation: (Bourkhis \& Nabi, 2013).

\section{Journal article with DOI}

Ichwan, M. (2012). The Local Politics Of Orthodoxy: The Majelis Ulama Indonesia in the Post-New Order Banten. Journal Of Indonesian Islam, 6(1), 166-194. doi:http://dx.doi.org/10.15642/JIIS.2012.6.1.166-194

In text citation : (Ichwan, 2012)

\section{Abstract as citation}

Hasan, N. (2012). Islamist Party, Electoral Politics And Da'wah Mobilization Among Youth : The Prosperous Justice Party (PKS) in Indonesia. Journal of Indonesian Islam, 6(1), 17-47. Abstract from http:// jiis.uinsby.ac.id/index.php/jiis/article/view/97

in text citation : (Hasan, 2012)

\section{Mass media article}

Sahal, Akhmad (2014, March 2). Kiai Sahal dan Realisme Fikih.Tempo Magazine, p. 120.

in text citation : (Sahal, 2014) 


\section{Research report}

Fisher, B. S., Cullen, F. T., \& Turner, M. G. (2000). The Sexual Victimization of College Women. Research Report.

in text citation : (Fisher, Cullen, Turner, 2000)

\section{Monograph}

Routray, Bibhu Prasad (2013), National Security Decision-Making in India (RSIS Monograph No. 27). Singapura: Rajaratnam School of International Studies.

in text citation : (Routray, 2013)

\section{Proceeding article}

Sudibyakto, Hizbaron, D.R., \& Jati, R (Ed.) (2009), Proceeding International Seminar Disaster Theory, Research and Policy. International seminar held by Sekolah Pascasarjana, Universitas Gajahmada, Yogyakarta, 8-9 Desember 2009.

in text citation : (sudibyakto and Jati, 2009)

\section{Paper conference/seminar/symposium}

Janutama, Herman Sinung (2011). "Kraton dan Hubungan Antar Agama." Paper presented in Seminar Kraton dan Panatagama held by Center for the Study of Islam and Social Transformation (CISForm), Yogyakarta, 17 November.

in text citation :(Janutama, 2011)

\section{Online article in web}

Shiva, (2006, February). Bioethics: A Third World Issue. Native-web. Diperoleh dari http://www.nativeweb.org/ pages/legal/shiva.html

in text citation : (Shiva, 2006) 


\section{Online research report}

Kessy, S. S. A., \& Urio, F M. (2006). The contribution of microfinance institutions to poverty reduction in Tanzania (Research Report No. 06.3). Retrieved from Research on Poverty Alleviation website: http://www. repoa.or.tz /documents_storage/Publications/Reports/06.3_Kessy_and_ Urio.pcif

in text citation : (kessy and urion, 2006)

\section{Holy book}

Qur an, $2(25)$

In text citation : (Q. al-Baqarah 2:25).

\section{Encyclopaedia}

Graycar, Adam (1992). Social Welfare Policy. Dalam Mary Hawkesworth dan Maurice Kogan (Ed.), Encyclopedia of Government and Politics (Vol. 1). London: Routledge.

in text citation : (Graycar, 1992)

\section{Interview}

Sultan Hamengkubuwono X (interview, 2011, April 19)

in text citation: (Hamengkubuwono, 2011)

\section{Documentary film}

Steijlen, Fridus (2008). A Day in the Life of Indonesia [documentary film, 58 minutes]. Leiden: KITLV Press.

in text citation : (Steijlen, 2008) 
Vol. 2 No. 1, January - April 2017 